\title{
Variation in Impedance Measurement in Cochlear Implant Children
}

\author{
Pradeep VR ${ }^{1 *}$ and TA Subba Rao ${ }^{2}$ \\ ${ }^{1} \mathrm{PhD}$ Scholar, Mangalore University, India \\ ${ }^{2}$ MV Shetty College of Speech \& Hearing, Mangalore University
}

Submission: April 15, 2019; Published: April 29, 2019

*Corresponding author: Pradeep VR, PhD Scholar, Mangalore University, India

\section{Introduction}

In pediatric cochlear implantation subjective measurement play a major role in finding functions of electrode. Impedance measurements are carried out in both intraoperative and postoperatively during switch-on. These measurements make possible to check, whether all electrodes functions correctly. The analysis of the impedances changes makes possible to guess, what processes happen in tissues and liquids of the inner ear around the electrode. In Cochlear implant the communication between the internal component of implanted electrode and the external speech processor signal is monitored or checked via Custom Sound Software. Neural Response Telemetry (NRT) gives us clear information about the impedance of the electrode, electrodes position, electrical problems like short circuit and open circuit, failure of electrode during the time of surgery and post-surgery can be monitored [1]. In Neural Response Telemetry (NRT) the impedance of the electrodes is a method of measuring resistance encountered by electricity passing through wires, electrodes and biological tissue [2]. It is calculated as the ratio of the effective voltage applied to a particular circuit and the actual amount of electrical power intensity absorbed by the circuit. The unit of impedance is the ohm. The electrodes impedance does not confirm the electrode placement and neither replace the radiographies after the implant [3].

\section{The aim of the study}

The aim of the study was to measure the change in impedance values of cochlear implant children during the time of surgery, and the cochlear implant Sound/Speech processor switch on (1 month postoperatively).

\section{Material and methods}

In current study 100 children whose age range are from 18 to 60 months with bilateral profound hearing loss has been operated with Cochlear Nucleus CI24RE (ST) Implants on one side. The impedance values are measured for all 22 electrodes with help of Custom Sound EP, Custom Sound software and Nucleus CP802 Speech Processor. The impedance of electrodes in cochlear implants users was measured during time of surgery and postoperative while switching on the speech processor.

\section{Results}

We observed raised values of the impedance during the time of activation of the speech processor when compared to intraoperating measurement. Below chart explains current level of each electrodes function includes MP 1, MP2, Mp1+2 and common ground (Figures 1-3), (Table 1).

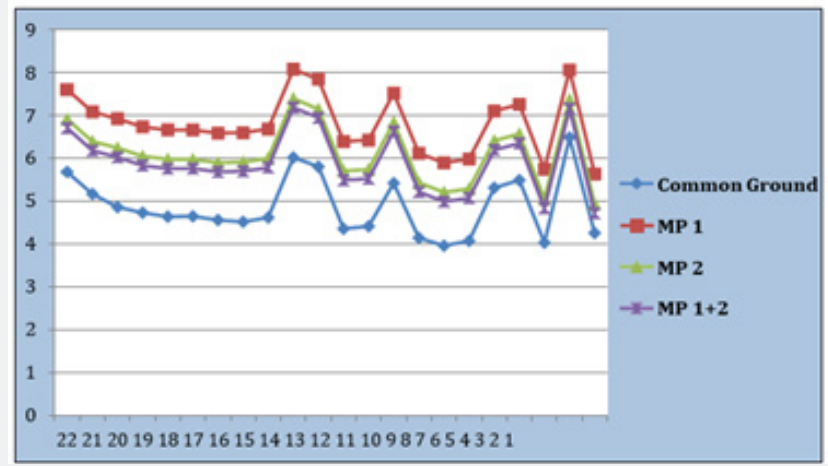

Figure 1: Average values of each active electrode impedance values during time of surgery. 


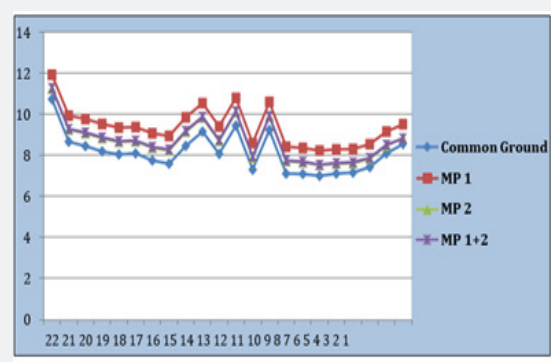

Figure 2: Average values of each active electrode impedance values during time of Speech Processor switch on after one month

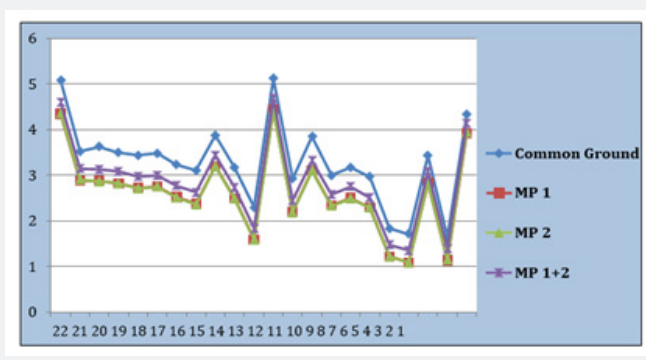

Figure 3: Average difference values of each active electrode impedance values during time of surgery \& Speech Processor switch on after one month.

Table 1: Below tabulate column explains average difference values of each active electrode impedance values during time of surgery \& Speech Processor switch on after one month.

\begin{tabular}{|c|c|c|c|c|}
\hline Electrode & Common Ground & MP 1 & MP 2 & MP $1+2$ \\
\hline 22 & 5.0774 & 4.3411 & 4.3609 & 4.5975 \\
\hline 21 & 3.5255 & 2.8775 & 2.8945 & 3.1394 \\
\hline 20 & 3.6185 & 2.8727 & 2.8676 & 3.1249 \\
\hline 19 & 3.4923 & 2.8186 & 2.8209 & 3.0796 \\
\hline 18 & 3.4402 & 2.7199 & 2.7098 & 2.969 \\
\hline 17 & 3.4789 & 2.7481 & 2.741 & 2.9928 \\
\hline 16 & 3.2231 & 2.5175 & 2.5073 & 2.7616 \\
\hline 15 & 3.1071 & 2.376 & 2.357 & 2.6271 \\
\hline 14 & 3.8723 & 3.1967 & 3.1896 & 3.439 \\
\hline 13 & 3.1664 & 2.491 & 2.4756 & 2.7262 \\
\hline 12 & 2.2986 & 1.5929 & 1.5921 & 1.8367 \\
\hline 11 & 5.1161 & 4.4295 & 4.4264 & 4.6895 \\
\hline 10 & 2.9213 & 2.199 & 2.1888 & 2.4502 \\
\hline 9 & 3.8448 & 3.1053 & 3.0905 & 3.3158 \\
\hline 8 & 3.0022 & 2.3368 & 2.3226 & 2.5747 \\
\hline 7 & 3.1696 & 2.4949 & 2.4844 & 2.7451 \\
\hline 6 & 2.9616 & 2.2811 & 2.2838 & 2.5008 \\
\hline 5 & 1.8338 & 1.2201 & 1.2181 & 1.4725 \\
\hline 4 & 1.7075 & 1.087 & 1.0857 & 1.3514 \\
\hline 3 & 3.4282 & 2.8266 & 2.8302 & 3.0797 \\
\hline 2 & 1.6416 & 1.1344 & 1.137 & 1.3917 \\
\hline 1 & 4.3233 & 3.9093 & 3.9424 & 4.1381 \\
\hline
\end{tabular}

\section{Conclusion}

Impedance decreases after first fitting but less than intraoperative measurement. Increasing values of impedance during first fitting of the speech processor support the hypothesis that a layer of fibrous tissue forms around the electrode because of the inflammatory changes or due to exudation of protein. This may suggest that electrical stimulation prevents adverse changes in the cochlea. The intra-operative impedance values and postoperative change in values are part of the common trend specific to each brand separately. Besides the parameters related to the device, the individual organic features of the inner ear may play an important role, as confirm by the patients from the latest study.

\section{References}

1. Schulman JH (1995) Using impedance telemetry to diagnose cochlear electrode history, location and functionality. Ann Otol Rhinol Laryngol 166 (Suppl): 85-87.

2. Finley CC, Holden TA, Holden LK, Whiting BR, Chole RA, et al. (2008) Role of Electrode Placement as a Contributor to Variability in Cochlear Implant Outcomes. Otol Neurotol 29(7): 920-928.

3. Dorman MF (1992) Long-term measures of electrode impedance and auditory thresholds for the Ineraid Cochlear Implant. J Sp Hear Res 35(5): 1126-1130. 
(C) This work is licensed under Creative (i) Commons Attribution 4.0 License BY DOI: 10.19080/GJO.2019.20.556029
Your next submission with Juniper Publishers will reach you the below assets

- Quality Editorial service

- Swift Peer Review

- Reprints availability

- E-prints Service

- Manuscript Podcast for convenient understanding

- Global attainment for your research

- Manuscript accessibility in different formats

( Pdf, E-pub, Full Text, Audio)

- Unceasing customer service

Track the below URL for one-step submission https://juniperpublishers.com/online-submission.php 